\title{
Changes in leg length and height during treatment with somatropin
}

\author{
J K H WALES AND R D G MILNER \\ Department of Paediatrics, Sheffield University Children's Hospital
}

SUMMARY Knemometry has been used in a short term double blind placebo controlled trial in 13 patients with normal variant short stature receiving treatment with somatropin to assess the power of the change in lower leg velocity at one month to predict the increase in height velocity at six months. Used in this way the method has a positive predictive value and sensitivity of $90 \%$ and a negative predictive value and specificity of $50 \%$. Although not a perfect discriminatory test, knemometry is a more reliable and less invasive way of analysing the likely value of a growth promoting treatment than metabolic assays in individual patients. Given the possible future rapid expansion of the use of somatropin in short stature of various aetiologies there is a need for a relatively simple and inexpensive means of evaluating response to treatment.

Knemometry provides a precise and reproducible means of measuring short term changes in lower leg length and is capable of detecting daily or weekly changes in lower leg length velocity. ${ }^{2}$ It is not possible to extrapolate changes in lower leg length directly to changes in stature because of the inherent variability of growth in lower leg length, which proceeds in a series of lulls and spurts, ${ }^{3}$ and to use the growth of a group of bones to mirror the growth of the entire skeleton is conceptually imprecise. Nevertheless we have previously shown (using knemometry) in patients with Turner's syndrome that failure to respond to somatrem during a four week period predicts failure to respond to a six month course of somatrem in the same dose assessed by auxology. ${ }^{4}$ The positive predictive power of knemometry was weaker in this model because apparent responses may have been the result of coincidental 'mini growth spurts'.

The possibility of a placebo effect of injections or of increased hospital attendance has never been satisfactorily excluded in trials of growth hormone treatment. A placebo controlled trial in the United Kingdom was in progress at the time of withdrawal of pituitary growth hormone in 1985 and no other placebo controlled study has ever been undertaken. ${ }^{5}$

Pituitary gigantism is the experiment of nature that testifies that any normal child can be made to grow faster and achieve a greater adult height if given sufficient growth hormone. Normal variant short stature is one of several terms used to describe short children who are growing slowly but who have peak plasma growth hormone responses to conventional testing of $>15 \mathrm{U} / \mathrm{l}$. This may represent the lower extreme of physiological growth hormone secretion in a range extending from classical growth hormone deficiency through short normal to tall normal children, ${ }^{6}$ although not all workers have found the association between stature and physiological growth hormone profiles to be as straightforward as was initially proposed. ${ }^{78}$

The dose response of normal variant short stature to treatment with growth hormone is not well defined. Previous reports indicate that about two thirds of such patients respond to a conventional dose of growth hormone of $2 \mathrm{U} / \mathrm{day}$, but whether more would respond if the dose were larger is unknown. ${ }^{910}$

At present the identification of benefit from any growth promoting treatment requires conventional auxology for at least six months and is usually defined as an increase in height velocity of $>2 \mathrm{~cm} / \mathrm{year}$. It should be remembered that benefit from growth hormone treatment in terms of increase in final adult height has not yet been shown apart from in patients with 'classical' growth hormone deficiency. If lack of response to a treatment protocol could be determined over a shorter period than six months (as seems to be the case in Turner's syndrome ${ }^{4}$ ) then an ineffective, expensive, and uncomfortable treatment could be withdrawn or modified with consequent benefit to the patient and financial saving. 
Table 1 Patients details at entry to trial. The patients are ranked according to eventual increase in height velocity

\begin{tabular}{|c|c|c|c|c|c|c|}
\hline $\begin{array}{l}\text { Case } \\
\text { No }\end{array}$ & Sex & $\begin{array}{l}\text { Age } \\
\text { (years) }\end{array}$ & $\begin{array}{l}\text { Bone age } \\
\text { at start of } \\
\text { treatment } \\
\text { (years) }\end{array}$ & $\begin{array}{l}\text { Height } \\
\text { (SD score) }\end{array}$ & $\begin{array}{l}\text { Height } \\
\text { velocity } \\
\text { (SD score) }\end{array}$ & $\begin{array}{l}\text { Target } \\
\text { height }^{*} \\
\text { (SD score) }\end{array}$ \\
\hline 1 & Female & $4 \cdot 1$ & $2 \cdot 8$ & -1.9 & $-1 \cdot 6$ & -0.7 \\
\hline 2 & Male & $11 \cdot 7$ & $8 \cdot 8$ & $-4 \cdot 6$ & $-3 \cdot 8$ & $-1 \cdot 4$ \\
\hline 3 & Male & $10 \cdot 8$ & $9 \cdot 3$ & $-2 \cdot 5$ & $-1 \cdot 4$ & Adopted \\
\hline 4 & Male & $4 \cdot 5$ & $3 \cdot 5$ & -2.9 & -1.9 & $+0 \cdot 3$ \\
\hline 5 & Male & $12 \cdot 7$ & $9 \cdot 2$ & $-3 \cdot 0$ & -1.6 & -1.5 \\
\hline 6 & Male & $13 \cdot 2$ & $10 \cdot 6$ & $-2 \cdot 3$ & $-3 \cdot 0$ & $-1 \cdot 2$ \\
\hline 7 & Female & $11 \cdot 1$ & $8 \cdot 8$ & $-3 \cdot 1$ & -0.7 & -0.4 \\
\hline 8 & Male & $5 \cdot 1$ & $3 \cdot 8$ & $-2 \cdot 8$ & $-2 \cdot 2$ & $+1 \cdot 3$ \\
\hline 9 & Male & $10 \cdot 3$ & $10 \cdot 3$ & $-2 \cdot 3$ & -0.5 & 0.0 \\
\hline 10 & Male & $5 \cdot 1$ & $2 \cdot 4$ & $-4 \cdot 4$ & $-2 \cdot 0$ & $-1 \cdot 5$ \\
\hline 11 & Male & $13 \cdot 6$ & $11 \cdot 8$ & $-2 \cdot 5$ & $-4 \cdot 5$ & -0.5 \\
\hline 12 & Male & $11 \cdot 7$ & $8 \cdot 6$ & $-4 \cdot 2$ & -0.8 & $-2 \cdot 9$ \\
\hline 13 & Female & $10 \cdot 8$ & $8 \cdot 5$ & $-2 \cdot 2$ & $-1 \cdot 9$ & -0.2 \\
\hline
\end{tabular}

${ }^{*}$ Target height $=$ (height of mother + height of father $) / 2$ where parental height is adjusted by adding $13 \mathrm{~cm}$ to the mothers' height in the case of a boy and subtracting $13 \mathrm{~cm}$ from fathers' height in the case of a girl.

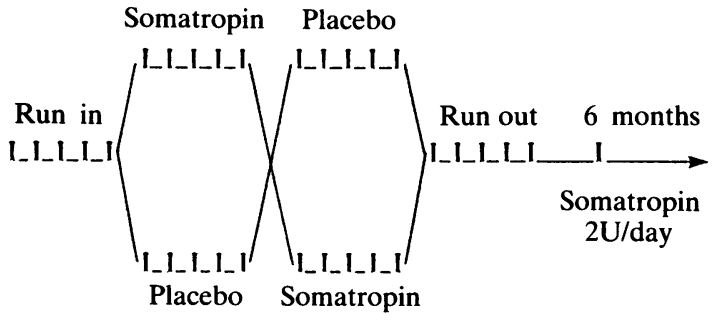

Figure Design of trial: weekly measurements for a minimum of 16 weeks followed by monthly measurements for six months. Somatropin was given in doses of $0.5 \mathrm{ml}$ or 2 U/day.

\section{Patients and methods}

Thirteen children with short stature (more than 2 SD below normal height for age) and a poor growth rate $(\leqslant 25$ th centile height velocity for chronological age) determined by accurate auxology for at least a year were recruited from patients referred to this hospital. Where it was possible to calculate the target height from the heights of the parent all were apparently failing to fulfill their genetic height potential. All had documented adequate plasma growth hormone concentrations in response to various provocation tests as defined by the former Health Services Human Growth Hormone Committee. ${ }^{11}$ All subjects were healthy and prepubertal by clinical criteria at the beginning and end of the study, and had a starting bone age of less than 11 years for girls and 12 years for boys.
Informed consent for participation in the trial was obtained from the children and parents, and the study was approved by the local ethics committee. Patient details at entry are given in table 1 .

The design of the trial is shown in the figure. The subjects were measured weekly for a minimum of 13 weeks. There was at least four weeks' 'run in' before two four week double blind periods of injection with placebo or somatropin before a four week 'run out' period. The placebo and somatropin were provided as identically packaged lyophilised powder by KabiVitrum AB, Stockholm, who held the code until the end of the trial. The patients received $0.5 \mathrm{ml}$ placebo, or the same volume, equivalent to $2 U$ somatropin, allocated at random, by daily subcutaneous injection. After the 16 week period of intensive measurement, the patients attended monthly for six months during which they received $2 \mathrm{U}$ somatropin daily.

At each visit four estimations were made of lower leg length and height, sitting height and weight were measured as previously described. ${ }^{2}$ The subjects attended for measurement on the same weekday at the same time of afternoon to correspond with the reported plateau of postural lower leg compression and kept daily activity as uniform as possible. ${ }^{12}$ Any changes in routine, or illnesses since the previous visit, were recorded and an enquiry was made at each visit for possible side effects or problems with treatment. A specimen of urine was tested for glucose at each visit and glycated haemoglobin was also measured at the end of the trial to detect clinically relevant glucose intolerance. A radiograph for the estimation of TW2 bone maturation index was taken at the start and the end of the study. ${ }^{13}$ 
The design of the trial permitted determination of: (i) The ability of knemometry to detect active growth promoting treatment by an acceleration in lower leg velocity. If there was no short term response this could be either a failure of treatment (as shown subsequently from analysis of height velocity) or a failure of the method. (ii) Detection of a short term placebo effect of injections. (iii) The power of short term lower leg velocity changes to predict subsequent clinically significant height response to treatment with growth hormone defined conventionally as an increase in height velocity of more than $2 \mathrm{~cm} /$ year.

After all the patients had completed the trial, rates of lower leg growth during the intensive measurement phase were calculated by linear regression through the median lower leg estimation, as described previously. ${ }^{2}$ Unlike height velocity, positive lower leg response was not defined numerically. The higher lower leg velocity was used to predict the active phase of treatment and the analysis sent to KabiVitrum. Only then was the code broken and the actual treatment order established. The predictive power of knemometry was calculated by comparing short term positive and negative responses with the positive and negative responses in the six month height velocity. ${ }^{14}$

There were no defaulters at any planned visit and the injections were well tolerated. One child withdrew from the study after the intensive period of measurement and her data are not included in the analysis of predictive power of knemometry.

\section{Results}

There was no significant difference between lower leg growth during the run in and run out phases, and so these have been combined as a 'no treatment' velocity $(\mathrm{N})$ and compared with velocity during placebo (P) or active treatment (S) in table 2. The following patterns of response were seen: $\mathrm{S}>\mathrm{P}>\mathrm{N}=5 ; \quad \mathrm{S}>\mathrm{N}>\mathrm{P}=4 ; \quad \mathrm{S}>\mathrm{P}=\mathrm{N}=2 ; \quad$ in other words knemometry was able to detect the active component in 11 of 13 subjects. In one child $\mathrm{N}>\mathrm{S}>\mathrm{P}$ and in another $\mathrm{P}>\mathrm{N}>\mathrm{S}$. There was no detectable placebo effect in that $\mathbf{P}$ was greater than $\mathrm{N}$ on six occasions, equal on two occasions, and less than $\mathrm{N}$ on four occasions. There was no association of treatment order S-P or P-S to magnitude of lower leg response, and thus no delayed treatment effect of somatropin on lower leg growth.

As there was no placebo effect, a mean was taken of all lower leg velocities during periods without active treatment $(\mathrm{P}+\mathrm{N} 1+\mathrm{N} 2 / 3)$ and the value was subtracted from the lower leg velocity when taking somatropin (S) to show the change that may be seen in patients with normal variant short stature.

The bone age gap (chonological age-bone age) and height velocity of each child at the end of the study and the changes in these two measurements as

Table 2 Lower leg velocity ( $\mathrm{mm} /$ week) during the three phases of intensive measurement, all phases when growth hormone was not given combined, and the difference between lower leg velocities with and without short term treatment with growth hormone

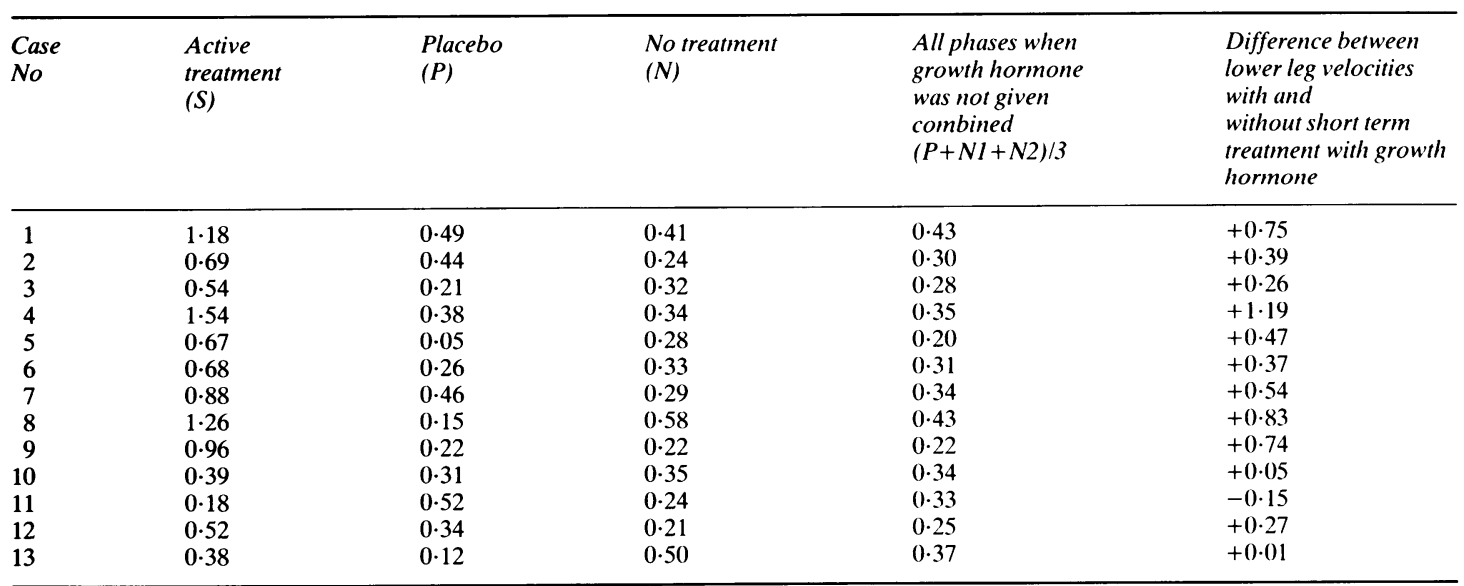


Table 3 Patients' ages at entry to trial; chronological/bone age gaps and height velocities at start and finish of trial, and changes in these values

\begin{tabular}{|c|c|c|c|c|c|c|c|}
\hline \multirow{2}{*}{$\begin{array}{l}\text { Case } \\
\text { No }\end{array}$} & \multirow{2}{*}{$\begin{array}{l}\text { Age } \\
\text { (years) }\end{array}$} & \multicolumn{2}{|l|}{ Before trial } & \multicolumn{2}{|l|}{ After trial } & \multicolumn{2}{|l|}{ Change } \\
\hline & & $\begin{array}{l}\text { Chronological/bone } \\
\text { age gap } \\
\text { (years) }\end{array}$ & $\begin{array}{l}\text { Height } \\
\text { velocity } \\
\text { (cm/year) }\end{array}$ & $\begin{array}{l}\text { Chronologicallbone } \\
\text { age gap } \\
\text { (years) }\end{array}$ & $\begin{array}{l}\text { Height } \\
\text { velocity } \\
\text { (cm/year) }\end{array}$ & $\begin{array}{l}\text { Chronological/bone } \\
\text { age gap } \\
\text { (years) }\end{array}$ & $\begin{array}{l}\text { Height } \\
\text { velocity } \\
\text { (cm/year) }\end{array}$ \\
\hline 1 & $4 \cdot 1$ & $1 \cdot 3$ & $5 \cdot 9$ & $1 \cdot 7$ & $12 \cdot 5$ & +0.4 & $+6 \cdot 7$ \\
\hline 2 & $11 \cdot 7$ & $2 \cdot 9$ & $2 \cdot 1$ & $3 \cdot 4$ & $6 \cdot 7$ & +0.5 & $+4 \cdot 6$ \\
\hline 3 & $10 \cdot 8$ & $1 \cdot 5$ & $4 \cdot 1$ & $1 \cdot 7$ & $8 \cdot 4$ & $+0 \cdot 2$ & $+4 \cdot 3$ \\
\hline 4 & $4 \cdot 5$ & $1 \cdot 0$ & $5 \cdot 4$ & $1 \cdot 5$ & $9 \cdot 6$ & +0.5 & $+4 \cdot 2$ \\
\hline 5 & $12 \cdot 7$ & $3 \cdot 5$ & $4 \cdot 1$ & $3 \cdot 7$ & $7 \cdot 7$ & +0.2 & $+3 \cdot 6$ \\
\hline 6 & $13 \cdot 2$ & $2 \cdot 6$ & $4 \cdot 1$ & $2 \cdot 6$ & $7 \cdot 6$ & $0 \cdot 0$ & $+3 \cdot 5$ \\
\hline 7 & $11 \cdot 1$ & $2 \cdot 3$ & $4 \cdot 7$ & $2 \cdot 4$ & $8 \cdot 1$ & $+0 \cdot 2$ & $+3 \cdot 4$ \\
\hline 8 & $5 \cdot 1$ & $1 \cdot 3$ & $4 \cdot 7$ & 1.4 & $7 \cdot 6$ & $+0 \cdot 1$ & $+2 \cdot 9$ \\
\hline 9 & $10 \cdot 3$ & $0 \cdot 0$ & $3 \cdot 6$ & $-0 \cdot 2$ & $6 \cdot 2$ & $-0 \cdot 2$ & $+2 \cdot 6$ \\
\hline 10 & $5 \cdot 1$ & $2 \cdot 7$ & $4 \cdot 7$ & $3 \cdot 0$ & $7 \cdot 2$ & $+0 \cdot 3$ & $+2 \cdot 5$ \\
\hline 11 & $13 \cdot 6$ & $1 \cdot 8$ & $3 \cdot 5$ & $2 \cdot 0$ & $4 \cdot 8$ & $+0 \cdot 2$ & $+1 \cdot 3$ \\
\hline 12 & $11 \cdot 7$ & $3 \cdot 1$ & $4 \cdot 5$ & $3 \cdot 3$ & $5 \cdot 8$ & $+0 \cdot 2$ & $+1 \cdot 3$ \\
\hline
\end{tabular}

a result of treatment with somatropin are shown in table 3 . All 12 subjects remaining in the trial showed an increased height velocity (mean $+3.4 \mathrm{~cm} /$ year; range $+1 \cdot 3$ to $+6 \cdot 7$ ), but this was not deemed to be clinically relevant in two children who did not achieve the previously defined increase of $+2 \mathrm{~cm} /$ year. ${ }^{15}$ There was a significant increase of the bone age gap in the group as a whole $(p=<0.01)$ and hence an improved adult height prediction in eight of 10 responders to somatropin. There was no correlation between six month height velocity response to age, peak growth hormone response to stimulation tests, previous height SD score, previous height or lower leg velocity, and dose of somatropin. There was a weak and not significant $(r=0.48)$ linear correlaton between increase in height velocity and magnitude of lower leg response. No side effects of treatment were reported, nor was there any glycosuria. Glycated haemoglobin concentrations at the end of the trial were within the normal range in all cases.

Comparing the concordance of short term and long term reponses shows that nine subjects responded in both the short term and the long term, one subject did not respond in either the short term or the long term, but more importantly there were two subjects who were discordant. Of the two discordant children one showed no apparent increase in lower leg velocity but did have an increased height velocity of $2.4 \mathrm{~cm} /$ year, a false negative response. Knemometry had a $90 \%$ positive predictive value and $90 \%$ sensitivity for the response to treatment with somatropin in patients with normal variant short stature judged conventionally, and a $50 \%$ negative predictive value and specificity. The numbers studied (nine of 10 and one of two, respectively) are too few to warrant extrapolation of these percentages.

\section{Discussion}

Knemometry is a powerful method for examining short term changes in lower leg growth rate. Wit $\boldsymbol{e} t$ $a l$ have shown that lower leg growth of normal children in two successive six week periods varied significantly in 5 of 31 cases, and that to be confident at a $5 \%$ level that a change in lower leg growth was not a chance association with a growth spurt, a change in lower leg velocity of $>0.37 \mathrm{~mm} /$ week was necessary. ${ }^{16}$ Our trial of the predictive power of knemometry in Turner's syndrome confirmed that a short term growth response had only a $50 \%$ predictive value for a six month response, but had an excellent negative predictive value of $100 \%{ }^{4}$ This led to the proposal that knemometry could be used to screen children who would not respond to a long term therapeutic growth promoting regimen.

In patients with Turner's syndrome we showed a clear bimodal lower leg response to short term somatrem, with a range of short term lack of response of -0.55 to $+0 \cdot 14$, and of response from 0.31 to $0.67 \mathrm{~mm} /$ week. In this study we chose not to extrapolate from the results of the trial in patients with Turner's syndrome, or from the conclusions of Wit $e t$ al to preset a definition of what constituted a short term response in patients with normal variant short stature, but took the greater lower leg velocity on treatment as predictive of the active component and used the subsequent height velocity response to 
determine whether we could set a threshold of lower leg response that could be used as a screening test in future studies.

The double blind placebo controlled design of this study provided a more rigorous means of testing this proposal in these patients, who are likely to provide the greatest future demand for treatment with somatropin. We have confirmed that there is no placebo response to treatment that is detectable by knemometry, and that $2 \mathrm{U} / \mathrm{day}$ somatropin increased lower leg velocity by $0.25 \mathrm{~mm} /$ week or more in 10 of 13 subjects. The results of the present study differ from those of our study in patients with Turner's syndrome in that most patients responded to somatropin in the long term, and there was an example of a false negative short term response. Analysis of the predictive power of knemometry using the results of both studies gives a positive predictive value of $72 \%$, a negative predictive value of $86 \%$, a sensitivity of $93 \%$ and specificity of $55 \%$.

Knemometry is at least as accurate as measurement of metabolic variables such as nitrogen retention, ${ }^{17}$ assay of insulin like growth factor $1,{ }^{18-21}$ and growth hormone profile analysis ${ }^{8}$ in predicting response to treatment with somatropin. Assay of procollagen III related peptides measures the short term metabolic consequence of active growth, but is likely to show exactly the same variability as knemometry. ${ }^{22}$ Although there is a weak correlation for the group as a whole, the inherent variability of lower leg growth means that it is not possible to predict the magnitude of later height velocity response for an individual child, and that prediction of a good response to treatment is less certain than prediction of poor response. Although not ideal, we consider that there is a place for this technique in the evaluation of growth promoting regimens.

We thank KabiVitrum AB for the provision of the preparations used in this study, and Mrs M Pickering and Mrs R White for collecting the measurements and performing the TW2 analysis.

\footnotetext{
References

1 Wales JKH, Milner RDG. Variation in lower leg growth with alternate day steroid treatment. Arch Dis Child 1988;63:981-3.

2 Wales JKH, Milner RDG. Knemometry in assessment of linear growth. Arch Dis Child 1987:62:166-71.

3 Hermanussen M, Geiger-Benoit K. Burmeister J, Sippel WG. Periodical changes of short term growth velocity ("mini growth spurts') in human growth. Ann Hum Biol 1988;15:103-9.

+ Wales JKH, Milner RDG. Knemometry as a predictor of
}

response to somatrem in Turner's syndrome. Acta Paediatr Scand 1987;337(suppl):37-9.

5 Buchanan CR, Law CM, Milner RDG. Growth hormone in short, slowly growing children and those with Turner's syndrome. Arch Dis Child 1987;62:912-6.

- Albertsson-Wikland K, Isaksson O, Rosberg S, Westphal O. Secretory pattern of growth hormone in children of different growth rates. Acta Endocrinol 1983;103(suppl 256):72.

7 Rose SR, Ross JL, Uriarte M, Barnes KM, Cassorla FG, Cutler GB. The advantage of measuring stimulated as compared with spontaneous growth hormone levels in the diagnosis of growth hormone deficiency. $N$ Engl J Med 1988;319:201-7.

${ }^{8}$ Costin G, Kaufman FR. Growth hormone secretory patterns in children with short stature. J Pediatr 1987;110:362-8.

" Van Vliet G, Styne DM, Kaplan SL, Grumbach MM. Growth hormone treatment for short stature. $N$ Engl $J$ Med 1983;309:1016-22.

10 Raiti S, Kaplan SL, Van Vliet G, Moore WV. Short-term treatment of short stature and subnormal growth rate with human growth hormone. J Pediatr 1987;110:357-61.

1 Milner RDG, Burns EC. Investigation of suspected growth hormone deficiency. Arch Dis Child 1982:57:944-7.

12 Valk IM, Langhout Chabloz AME, van Gilst W. Intradaily variation of the human lower leg length and short term growtha longitudinal study in fourteen children. Growth 1983;47: 397-402.

13 Tanner JM, Whitehouse RH, Marshall WA, Healy MJR, Goldstein $\mathrm{H}$. Assessment of skeletal maturity and prediction of adult height. (TW2 method). London: Academic Press, 1975.

14 Vecchio TJ. Predictive value of a single diagnostic test in unselected populations. $N$ Engl J Med 1966;274:1171-3.

15 Milner RDG, Russell-Fraser T, Brook CGD, et al. Experience with human growth hormone in Great Britain: the report of the MRC Working Party. Clin Endocrinol 1979;11:15-38.

${ }^{16}$ Wit JM, van Kalsbeek EJ, van Wijk-Hoek JM, Leppink GJ Assessment of the usefulness of weekly knemometric measurements in growth studies. Acta Paediatr Scand 1987;76:974-80.

17 Wright JC, Brasel JA, Aceto T, et al. Studies with human growth hormone (HGH). Am J Med 1965;38:499-516.

18 Grunt JA, Howard CP, Daughaday WH. Comparison of growth and somatomedin $\mathrm{C}$ responses following growth hormone treatment in children with small-for-dates short stature, significant idiopathic short stature and hypopituitarism. Acta Endocrinol (Copenh) 1984;106:168-74.

19 Rudman D, Moffit SD, Fernhoff PM, McKenzie WJ, Kenny $\mathrm{JM}$, Bain RP. The relation between growth velocity and serum somatomedin C concentration. Journal of Endocrinology and Metabolism 1981;52:622-7.

20 Raiti S, Moore WV, Van Vliet G, Kaplan SL. Growthstimulating effects of human growth hormone therapy in patients with Turner's syndrome. J Pediatr 1986;109:944-9.

21 Gertner JM. Genel M, Gianfredi SP, et al. Prospective clinical trial of human growth hormone in short children without growth hormone deficiency. J Pediatr 1984:104:172-6.

22 Danne T. Grutes A. Schuppan D, Quantas N, Enders I, Weber B. Relationship of procollagen type III propeptide-related antigens in serum to somatic growth in healthy children and in patients with growth disorders. J Pediatr 1989:114:257-60.

Correspondence to Dr JKH Wales, Department of Paediatrics, Sheffield University Children's Hospital. Sheffield S10 2TH.

Accepted 10 July 1989 